\title{
A possible connection between circulating 25-hydroxy-vitamin D and molecular response in chronic myeloid leukemia
}

\author{
Gediz $\mathrm{F}^{1}$, Oruk $\mathrm{GG}^{2}$, Korkmaz $\mathrm{UB}^{3}$, Aksun $\mathrm{S}^{4}$, Calan $\mathrm{M}^{5}$, Savasoglu K $\mathrm{K}^{6}$, Yilmaz $\mathrm{AF}^{7}$, Payzin $\mathrm{KB}^{7}$ \\ Izmir Bozyaka Training and Research Hospital, Departmant of Hematology, Izmir, Turkey. \\ mdfusuncan@gmail.com
}

\author{
ABSTRACT \\ OBJECTIVE: In this study we aimed to evaluate whether there is a link between circulating 25-OH-D levels \\ and molecular response in chronic myeloid leukemia (CML). \\ MATERIAL AND METHOD: A total of 61 patients with CML (31 women, 30 men) were recruited in this cross- \\ sectional study. \\ RESULTS: Binary logistic regression analysis demonstrated that increased vitamin D levels were \\ independently associated with molecular response in subjects with CML. \\ CONCLUSION: Our results indicated for the first time in the literature that severe deficiency of vitamin D \\ was independently associated with molecular unresponsiveness in subjects with CML. 25-OH-D may be \\ contributing to molecular response in the patients (Tab. 3, Ref. 24). Text in PDF www.elis.sk. \\ KEY WORDS: chronic myeloid leukemia, vitamin D deficiency, molecular response.
}

\section{Introduction}

Vitamin D deficiency is a common problem all over the world. Approximately $25-50 \%$ of patients examined in routine clinical practice have vitamin $\mathrm{D}$ levels below the optimal range, and it is estimated that about 1 billion people have vitamin D insufficiency worldwide (1-3). Vitamin D is produced by skin exposure to sunlight (ie, ultraviolet B radiation) and it is also obtained from dietary sources including supplementation. Serum levels of 25-hydroxyvitamin D (25[OH]D) reflect whole-body vitamin D stores and are used to assess individual vitamin $\mathrm{D}$ adequacy or insufficiency. A low vitamin D level can be diagnosed using a blood test called 25-hydroxy vitamin D (25OHD). Although there is no formal definition of vitamin D deficiency, some groups use the following values in adults (3).

- A normal level of vitamin D is defined as a $25 \mathrm{OHD}$ concentration above $30 \mathrm{ng} / \mathrm{mL}$ ( $75 \mathrm{nmol} / \mathrm{L})$.

- Vitamin D insufficiency is defined as a $25 \mathrm{OHD}$ concentration of 20 to $30 \mathrm{ng} / \mathrm{mL}$ ( 50 to $75 \mathrm{nmol} / \mathrm{L}$ ).

- Vitamin D deficiency is defined as a 25OHD level below $20 \mathrm{ng} / \mathrm{mL}$ $(50 \mathrm{nmol} / \mathrm{L})$.

${ }^{1}$ Izmir Bozyaka Training and Research Hospital, Department of Hematology, ${ }^{2}$ Izmir Katip Celebi University Ataturk Training and Research Hospital, Department of Endocrinology, ${ }^{3}$ Izmir Katip Celebi University Ataturk Training and Research Hospital, Department of Internal Medicine, ${ }^{4}$ Izmir Katip Celebi University Ataturk Training and Research Hospital, Department of Biochemistry, ${ }^{5}$ Izmir Bozyaka Training and Research Hospital, Department of Endocrinology, and ${ }^{6}$ Izmir Katip Celebi University Ataturk Training and Research Hospital, Department of Genetic

Address for correspondence: F. Gediz, 35360 Izmir, Turkey.

Phone: +905066268179 , Fax: +902322431530
$25(\mathrm{OH}) \mathrm{D}$ is converted to 1,25-dihydroxyvitamin D $(1,25[\mathrm{OH}] 2 \mathrm{D})$, the physiologically active form of vitamin $\mathrm{D}$, via the action of 1-hydroxylase primarily in the kidneys. Once formed, $1,25(\mathrm{OH}) 2 \mathrm{D}$ exerts its biologic effects by binding to the vitamin D nuclear transcription factor receptor, which regulates the expression of nearly 200 genes (4). Vitamin D has a central role in maintaining serum calcium and skeletal homeostasis, as well as several other cellular effects, including regulation of differentiation, proliferation, apoptosis, metastatic potential, and angiogenesis (5). Growing evidence suggest that there is a connection between vitamin D and cardiometabolic diseases and cancer. Several reports published recently suggest that low serum $25(\mathrm{OH}) \mathrm{D}$ levels may be associated with increased incidence of colorectal $(6,7)$, breast $(8,9)$ and other cancer types $(10)$. A population-based, doubleblind, randomized placebo-controlled trial found that women who increased their daily vitamin D intake by $1100 \mathrm{IU}$ reduced their risk of cancer by $60-77 \%$, in consistency with the results above (11).

Identification of Vitamin D Receptors (VDRs) in almost all immune system cells primarily in antigen-presenting cells such as active $\mathrm{T}$ and $\mathrm{B}$ lymphocytes, active macrophages and dendritic cells as well as their detection in many types of tissues, attracted attention of the researchers to the role of vitamin D in immune regulation. Although low levels of 25-OH-D were associated with various malignancies, the causal effect of vitamin D deficiency on the development of malignancy remains unknown. The evidence for the relation between vitamin D levels and the risk of solid tumor development is gradually increasing, but the risk of hematological malignancy development is still unknown.

Although many investigations were conducted in recent years on the effects of vitamin D levels on the prognosis of malignant diseases, there is not enough data yet in the literature concerning 
CML (chronic myelocytic leukemia) patients. It was aimed in this study to evaluate vitamin D levels and calcium bone metabolism in CML patients, and to assess the relationship between vitamin D levels and prognosis.

\section{Material and methods}

\section{Subjects}

In this cross-sectional study, 61 CML patients (31 women, 30 men) were recruited from hematology clinics of Katip Celebi University Ataturk Training and Research Hospital between June 2014 and September 2014. History of receiving vitamin D/Ca supplements and presence of other malignancies were exclusion criteria. The study was approved by the human research ethics committee of the hospital and informed consent was obtained from all participants. Vitamin D status was defined as; severe deficiency $\leq 10 \mathrm{ng} / \mathrm{ml}$; deficiency $10-20 \mathrm{ng} / \mathrm{ml}$; insufficiency $20-30 \mathrm{ng} / \mathrm{ml}$; sufficiency $\geq 30 \mathrm{ng} / \mathrm{ml}$ (3). Treatment responses were evaluated according to the ELN recommendations $(12,13)$.

\section{Bcr-abl}

RQ-PCR method was used for qualitative and quantitative analysis of BCR-ABL (b3a2/b2a2) fusion transcripts. RNA isolation from peripheral blood was performed with QIAamp RNA Blood Mini (Qiagen Inc. Valencia, CA.) Kit. RNA purity was analyzed by spectrophotometry in the absorbance range of 260-280 nm. RT kit (Qiagen, USA) kits was used for cDNA synthesis. BCR-ABL1 Mbcr IS-MMR Kit (Qiagen, USA) was used for RQPCR assays. PCR amplification and product analysis assay were performed on RG-6000 real-time instrument (Corbett ResearchAustralia). PCR conditions were performed according to the manufacturer's recommendations. Software Rotor Gene Q series 1.7 was used for qualitative and quantitative analysis.

\section{Vitamin D measurements}

25-hydroxy vitamin D blood samples of the subjects were collected into standard vacuum tubes containing separation gel, allowed for half an hour for the formation of clot, and then centrifuged for 10 minutes at $3500 \mathrm{rpm}$ to separate serum samples. All serum samples were stored frozen at $-80^{\circ} \mathrm{C}$ until the day of analysis. In all samples, 25-OH vitamin D3 levels were determined quantitatively using electrochemiluminescence immunoassay method by Cobas brand E601 model modular autoanalyser (HoffmanLa Roche, Grenzacherstrasse 124 CH-4070 Basel, Switzerland). The results were reported in $\mathrm{ng} / \mathrm{ml}$.

\section{Statistical analysis}

All analyses were performed using the Statistical Package for the Social Sciences Software, version 18.0 (SPSS Inc., Chicago, USA). The patients were divided into two groups according to their vitamin D levels (group $1 \leq 10 \mathrm{ng} / \mathrm{ml}$, group $2>10 \mathrm{ng} / \mathrm{ml}$ ) and these two groups were compared with respect to clinical and laboratory parameters using Mann-Whitney U test. The difference in gender distribution between the groups was analyzed by Chi-square analysis.
To evaluate the effects of vitamin D levels on molecular response, we used binary logistic regression analysis. In our model, molecular response was defined as a dependent variable and the subjects were categorized according to their vitamin D levels as $\leq 10 \mathrm{ng} / \mathrm{ml}$ and $>10 \mathrm{ng} / \mathrm{ml}$. In order to clarify the effect of potential confounders such as Sokal score, gender and type of treatment, we added these variables to the model consecutively. Confidence interval (CI) for all reported values was $95 \%$. A two-sided $p$ value of $<0.05$ was considered statistically significant.

\section{Results}

A total of 61 patients ( 31 women, 20 men) were included in the study. The mean age of the subjects was 54.5 years and the mean follow-up period was 5.65 years. Molecular response was determined in 36 of 61 patients included in the study. As for treatment, Imatinib was used in 46 patients, Dasatinib in 7, Nilotinib in 7 and Hydroxyurea in 1 patient. Patients' data with respect to demographic characteristics and laboratory values are shown in Table 1.

As for vitamin D levels; 37 (60.7\%) patients had $\leq 10 \mathrm{ng} / \mathrm{ml}$, $19(31.1 \%)$ patients had $10-20 \mathrm{ng} / \mathrm{ml}$ and $5(8.2 \%)$ patients had 20-30 $\mathrm{ng} / \mathrm{ml}$. None of the subjects in our study population had sufficient levels of Vitamin D. In our study, patients were divided

Tab. 1. Demgraphic and laboratory characteristics of the subjects $(n=61)$.

\begin{tabular}{|c|c|}
\hline Variables & Mean \pm SD \\
\hline Age (years) & $54.39 \pm 15.21$ \\
\hline Follow-up (years) & $5.65 \pm 3.22$ \\
\hline Gender $(\mathrm{F} / \mathrm{M})$ & $31 / 30$ \\
\hline WBC $(103 / \mu \mathrm{L})$ & $7100 \pm 3200$ \\
\hline $\mathrm{Hgb}(\mathrm{mg} / \mathrm{dl})$ & $12.38 \pm 1.61$ \\
\hline PLT $(103 / \mu \mathrm{L})$ & $232.000 \pm 77.000$ \\
\hline Sokal score & $0.97 \pm 0.18$ \\
\hline Creatinine (mg/dl) & $0.89 \pm 0.28$ \\
\hline ALT (U/L) & $21.11 \pm 19.31$ \\
\hline $\mathrm{LDH}(\mathrm{U} / \mathrm{L})$ & $216.31 \pm 55.04$ \\
\hline PTH (pg/dl) & $98.12 \pm 54.24$ \\
\hline 25-OH-D & $10.00 \pm 5.49$ \\
\hline$\leq 10 \mathrm{ng} / \mathrm{ml}, \mathrm{n}(\%)$ & $37(60.7)$ \\
\hline $10-20$ ng/ml, n (\%) & $19(31.1)$ \\
\hline $20-30$ ng/ml, n (\%) & $5(8.2)$ \\
\hline $\mathrm{Ca}(\mathrm{mg} / \mathrm{ml})$ & $9.10 \pm 0.44$ \\
\hline $\mathrm{P}(\mathrm{mg} / \mathrm{ml})$ & $3.02 \pm 0.72$ \\
\hline Albumin $(\mathrm{mg} / \mathrm{ml})$ & $4.20 \pm 0.26$ \\
\hline 24-hour urine $\mathrm{Ca}$ extraction $(\mathrm{mg})$ & $99.09 \pm 67.05$ \\
\hline \multicolumn{2}{|l|}{ Co-morbidities } \\
\hline Type 2 diabetes, $\mathrm{n}(\%)$ & $12(19.6)$ \\
\hline Hyperlipidaemia, n (\%) & $14(22.9)$ \\
\hline Hypertension, n (\%) & $15(24.5)$ \\
\hline Coronary artery disease, $\mathrm{n}(\%)$ & $8(13.1)$ \\
\hline \multicolumn{2}{|l|}{ Treatment } \\
\hline Imatinib, n (\%) & $46(75.4)$ \\
\hline Dasatinib, n (\%) & $7(11.5)$ \\
\hline Nilotinib, n (\%) & $7(11.5)$ \\
\hline Hydroxyurea, n (\%) & $1(1.6)$ \\
\hline
\end{tabular}


Tab. 2. Comparison of the demographic and laboratory characteristics of the subjects according to vitamin $D$ levels $(\leq 10 \mathrm{ng} / \mathrm{ml}$ and higher vitamin $D$ levels $)$.

\begin{tabular}{lccc}
\hline Variables & $\leq 10 \mathrm{ng} / \mathrm{ml}(\mathrm{n}=37)$ & $>10 \mathrm{ng} / \mathrm{ml}(\mathrm{n}=24)$ & $\mathrm{p}^{\mathrm{a}}$ \\
\hline Age $($ years $)$ & $60.00(49.50-66.00)$ & $49.50(36.75-64.75)$ & 0.109 \\
\hline Gender $(\mathrm{F} / \mathrm{M})$ & $19 / 18$ & $12 / 12$ & 0.918 \\
\hline Disease duration (years) & $6.33(3.00-8.00)$ & $5.50(3.29-7.00)$ & 0.500 \\
\hline Sokal score & $1.03(0.91-1.10)$ & $0.90(0.72-1.14)$ & 0.246 \\
\hline $\mathrm{WBC} 10^{3} / \mu \mathrm{L}$ & $6660(5085-7900)$ & $6235(5090-7922)$ & 0.685 \\
\hline $\mathrm{Hbg}(\mathrm{ml} / \mathrm{dl})$ & $12.50(11.05-12.90)$ & $13.25(12.02-13.80)$ & $0.016^{*}$ \\
\hline PLT $10^{3} / \mu \mathrm{L}$ & $231(175-287)$ & $212(170-254)$ & 0.447 \\
\hline PTH $(\mathrm{pg} / \mathrm{mL})$ & $120.00(58.00-144.00)$ & $64.00(44.00-98.00)$ & $0.007^{*}$ \\
\hline Albumin $(\mathrm{mg} / \mathrm{dl})$ & $4.20(4.05-4.30)$ & $4.30(4.10-4.40)$ & 0.133 \\
\hline Ca $(\mathrm{mg} / \mathrm{dl})$ & $9.20(8.95-9.40)$ & $9.25(8.65-9.40)$ & 0.767 \\
\hline $\mathrm{P}(\mathrm{mg} / \mathrm{dl})$ & $3.10(2.65-3.60)$ & $2.95(2.30-3.62)$ & 0.375 \\
\hline 24-hour urine Ca $(\mathrm{mg})$ & $70.00(40.00-135.00)$ & $100.00(60.00-160.00)$ & 0.239 \\
\hline Creatinine $(\mathrm{mg} / \mathrm{dl})$ & $0.80(0.70-1.04)$ & $0.83(0.76-0.97)$ & 0.399 \\
\hline ALT $(\mathrm{U} / \mathrm{L})$ & $17.00(10.00-20.50)$ & $17.00(14.00-26.75)$ & 0.155 \\
\hline Molecular response, $\mathrm{n}(\%)$ & $18(48.6)$ & $18(59.0)$ & $0.041^{*}$ \\
\hline
\end{tabular}

Tab. 3. Logistic regression analysis for molecular response across $\leq \mathbf{1 0}$ $\mathrm{ng} / \mathrm{ml}$ or higher vitamin D levels.

\begin{tabular}{lccc}
\hline & OR & $95 \%$ CI & $p$ \\
\hline Model 1 & 3.167 & $1.026-9.770$ & $0.024^{*}$ \\
\hline Model 2 & 2.341 & $1.126-4.867$ & $0.032^{*}$ \\
\hline Model 3 & 2.338 & $1.122-4.871$ & $0.034^{*}$ \\
\hline Model 4 & 2.336 & $1.103-4.947$ & $0.037^{*}$ \\
\hline
\end{tabular}

OR - odds ratio, CI - confidence interval. A p value of $<0.05$ was considered significant $(*)$.

into two groups according to vitamin D levels: $<10 \mathrm{ng} / \mathrm{ml}$ and $>10 \mathrm{ng} / \mathrm{ml}$. There was no significant difference between the two groups in terms of age, gender, disease duration, Ca-P levels, and creatinine levels. Patients with lower vitamin D levels had lower levels of hemoglobin and PTH. The distribution of demographic and laboratory levels of the patients with respect to vitamin D levels is shown in Table 2. Molecular response was determined in 18 of the 37 patients $(48.6 \%)$ with low levels of vitamin D while 18 of the 24 patients $(59.0 \%)$ with high levels of vitamin D and the difference was statistically significant $(p=0.041)$.

\section{Discussion}

In the present study, we demonstrated for the first time that lower circulating 25-OH-D levels were independently associated with molecular unresponsiveness in subjects with chronic myeloid leukemia, after adjusting for potential confounders.

Epidemiological studies showed that reduced vitamin D levels may be related with increased cancer incidence and mortality (14, 15). This hypothesis has been further supported by studies showing that activated vitamin $\mathrm{D}$ receptor induced differentiation and apoptosis whereas inhibited proliferation, invasion and angiogenesis (16). Previous studies have also shown an inhibitory effect of vitamin D on megakaryocyte proliferation and collagen synthesis in the bone marrow $(22,23)$. It was thought that Vitamin D activity was associated with the reduction of the bone marrow col- lagen content, and on the opposite side, its deficiency was associated with abnormal accumulation of collagen in the bone marrow.

In a recent study by Campiotti et al, CML patients treated with tyrosine kinase inhibitors were followed-up and vitamin D levels were found to be higher in patients with complete molecular response with respect to those with major molecular responses. In addition, side effects of tyrosine kinase inhibitor treatment were found to be more common in patients with lower levels of vitamin D (24). That study supported the relation between vitamin D levels and treatment response as well as treatment-related side effects.

In a study searching for any correlation between vitamin D levels and prognosis in myeloproliferative diseases and MDS, vitamin D levels showed no relation with prognosis in polycythemia vera, myelofibrosis and MDS, in contrast to what was observed in CML (18). In another study, however, vitamin D therapy was shown to improve prognosis in MDS (19). Shanafelt et al followed the process from diagnosis to treatment prospectively in CLL patients, and determined that treatment procedures had to be initiated earlier in patients with vitamin D deficiency (17).

A pooled analysis of 10 studies found that higher levels of recreational sun exposure, which would be anticipated to increase vitamin D levels, was associated with a lower risk for non-Hodgkin lymphoma (21). Also, a meta-analysis showed a statistically significant protective effect of sunlight/UVR exposure on nonHodgkin lymphoma (20).

There are some limitations in the current study. The population size was relatively small and the cross-sectional study design cannot prove causality. In such a pioneering study on this topic, our findings are promising, but this association should be verified in a larger population using a prospective-cohort design. In brief, our results indicate for the first time that decreased circulating 25-OH-D levels were associated with molecular unresponsiveness in patients with CML. 25-OH-D may contribute to molecular response in CML patients. To our knowledge, there is no data in the literature on the relationship between vitamin $\mathrm{D}$ and molecular response in patients with CML.

As a result; there are studies showing that vitamin D levels are associated with prognosis in various hematological malignancies. In this study too, vitamin D levels were determined to affect the molecular response in CML. We suggest that vitamin D levels should be measured in patients with hematological malignancy and vitamin $\mathrm{D}$ replacement therapy should be performed in patients with vitamin D deficiency.

\section{References}

1. Thomas MK, Lloyd-Jones DM, Thadhani RI et al. Hypovitaminosis D in medical inpatients. N Engl J Med 1998; 338 (12): 777-783. 
2. Holick MF. High prevalence of vitamin D inadequacy and implications for health. Mayo Clin Proc 2006; 81 (3): 353-373.

3. Lavie CJ, Lee JH, Milani R V. Vitamin D and cardiovascular disease will it live up to its hype? J Am Coll Cardiol 2011; 58 (15): 1547-1556.

4. Carlberg C. Current understanding of the function of the nuclear vitamin D receptor in response to its natural and synthetic ligands. Recent Results Cancer Res 2003; 164: 29-42.

5. 5- Bikle D. Nonclassic actions of vitamin D. J Clin Endocrinol Metab 2009; 94 (1): 26-34.

6. Gorham ED, Garland CF, Garland FC et al. Vitamin D and prevention of colorectal cancer. J Steroid Biochem Mol Biol 2005; 97 (1-2): 179-194.

7. Yin L, Grandi N, Raum E et al. Meta-analysis: longitudinal studies of serum vitamin D and colorectal cancer risk. Aliment Pharmacol Ther 2009; 30 (2): 113-125.

8. Crew KD, Shane E, Cremers S et al. High prevalence of vitamin D deficiency despite supplementation in premenopausal women with breast cancer undergoing adjuvant chemotherapy. J Clin Oncol 2009; 27 (13): 2151-2156.

9. Chen P, Hu P, Xie D et al. Meta-analysis of vitamin D, calcium and the prevention of breast cancer. Breast Cancer Res Treat 2010; 121 (2): 469-477.

10. Garland CF, Gorham ED, Mohr SB, Garland FC. Vitamin D for cancer prevention: global perspective. Ann Epidemiol 2009; 19 (7): 468-483.

11. Lappe JM, Travers-Gustafson D, Davies KM et al. Vitamin D and calcium supplementation reduces cancer risk: results of a randomized trial. Am J Clin Nutr 2007; 85 (6): 1586-1591.

12. Baccarani M, Saglio G, Goldman $\mathbf{J}$ et al. Evolving concepts in the management of chronic myeloid leukemia: recommendations from an expert panel on behalf of the European LeukemiaNet. Blood 2006; 108 (6): 1809-1820.

13. Baccarani M, Cortes J, Pane F et al. Chronic myeloid leukemia: an update of concepts and management recommendations of European LeukemiaNet. J Clin Oncol 2009; 27 (35): 6041-6051.
14. Freedman DM, Looker AC, Chang SC, Graubard BI. Prospective study of serum vitamin D and cancer mortality in the United States. J Natl Cancer Inst 2007; 99: 1594-1602.

15. Giovannucci E, Liu Y, Rimm EB et al. Prospective study of predictors of vitamin D status and cancer incidence and mortality in men. J Natl Cancer Inst 2006; 98: 451-459.

16. Holick MF. Vitamin D; its role in cancer prevention and treatment. Prog Biophys Mol Biol 2006; 92: 549-559.

17. Shanafelt TD, Drake MT, Maurer MJ, et al. Vitamin D insufficiency and prognosis in chronic lymphocytic leukemia. Blood 2011; 117 (5): 1492-1498.

18. Pardanani A, Drake MT, Finke $C$ et al. Vitamin D insufficiency in myeloproliferative neoplasms and myelodysplastic syndromes: clinical correlates and prognostic studies. Am J Hematol 2011, 86: 1013-1016.

19. Mellibovsky L, Diez A, Perez-Vila E et al. Vitamin D treatment in myelodysplastic syndromes. Brit J Haematol 1998, 100; 516-520.

20. Park HY, Hong YC, Lee K, Koh J. Vitamin D status and risk of non-Hodgkin lymphoma: An updated meta-analysis. PLoS ONE 2019; 14 (4): e0216284

21. Kricker A, Armstrong BK, Hughes AM, Goumas C, Smedby KE, Zheng $\mathbf{T}$ et al; Interlymph Consortium. Personal sun exposure and risk of non-Hodgkin lymphoma: a pooled analysis from the Interlymph Consortium. Int J Cancer 2008; 122 (1): 144-154.

22. McCarthy DM, Hibbin JA, Goldman JM. A role for 1,25-dihydroxyvitamin D3 in control of bone-marrow collagen deposition? Lancet 1984; 1: 78-80.

23. Arlet P, Nicodeme R, Adoue $D$ et al. Clinical evidence for 1,25-dihydroxycho- lecalciferol action in myelofibrosis. Lancet 1984; 1: 1013-1014.

24. Campiotti L, Bolzacchini E, Sutter MB et al. Vitamin D and tyrosine kinase inhibitors in chronic myeloid leukemia. InternEmergency Med 2018; 8: 1337-1339.
Received October 20, 2019. Accepted February 14, 2020. 